Hale, C. M. F. \& Bisset, K. A. (1958). J. gen. Microbiol. 18, 688-691

\title{
The Pattern of Growth and Flagellar Development in Motile Gram-positive Cocci
}

\author{
By C. M. F. HALE AND K. A. BISSET \\ Department of Bacteriology, University of Birmingham
}

SUMMARY: By the use of a staining technique which enables the flagella and cell walls to be demonstrated simultaneously, the distribution of flagella on the component cells of motile Gram-positive cocci has been examined. By comparison of these preparations with others made by the technique of Pennington (1950), which indicates the physiological age of cells according to the resistance of their basophilic elements to the action of formaldehyde, it is apparent that such multicellular cocci divide in the manner already suggested for rod-shaped bacteria, not by simple fission but by a process analogous to budding, so that different cells in a group are at different physiological ages or stages of development.

The proposition that bacteria grow from one or both poles and divide by a process which resembles budding was advanced by Bisset (1951) and confirmed experimentally by Bisset \& Pease (1957). The main evidence is the arrangement of the flagella in growing and dividing cells, which is such as to suggest that the mother-cell retains most of its original cell wall and mature flagella, whereas the bud has a newly-grown cell wall with flagella in an early stage of development. It is of obvious interest to determine the arrangement of flagella upon dividing cells of motile cocci, but this is a task of greater complexity than the work with rod-shaped organisms, since it entails the simultaneous demonstration of the flagella and of the pattern of cross-walls dividing the cells of each group. The method to be described was eventually devised for this purpose, and it is remarkable that, although arrived at independently after prolonged trial and error, it proves to have some points in common with the technique of Shunk (1920), which was also claimed to show cell walls and flagella simultaneously, although no examples were published, and it is apparent that only the external wall was implied. The present method is less complicated and considerably less drastic.

In addition to the studies on flagellar pattern already described, a similar conclusion with respect to the division of bacteria into mother and daughter cells was reached by Pennington (1950) who showed that, after treatment with neutral formaldehyde, bacteria in young cultures retained their basophilia, whereas in older cultures they lost it. In rapidly growing cultures, recently divided pairs showed usually one 'old' and one 'young' cell. This method has now been applied to the motile cocci and provides evidence in support of the conclusions drawn from the observations on flagellar pattern. For purposes of comparison, some observations are included of the effect of this technique upon multicellular rod-shaped bacteria. 


\section{METHODS}

Six strains of motile Gram-positive cocci were examined. These included a stock culture of Sarcina ureae, two similar saprophytes isolated by Dr B. A. D. Stocker and Mr E. B. Pike, and three organisms isolated from fish by $\mathbf{M r}$ P. R. Hayes, to all of whom we are grateful. All grew at room temperature on nutrient agar. Actively motile cultures were examined at various ages from 8 to $24 \mathrm{hr}$. Suspensions of organisms were made in distilled water containing $0.5 \%(\mathrm{w} / \mathrm{v})$ formaldehyde, and air-dried smears were mordanted for at least $18 \mathrm{hr}$. at $20-25^{\circ}$ in a solution of $7 \cdot 5 \%(\mathrm{w} / \mathrm{v})$ tannic acid $+1 \%(\mathrm{w} / \mathrm{v})$ ferric chloride in water, washed and mordanted for a further $5 \mathrm{~min}$. in the same solution, with the addition of $1.5 \%(\mathrm{v} / \mathrm{v})$ of a second solution containing $10 \%(\mathrm{v} / \mathrm{v})$ aniline $+40 \%(\mathrm{v} / \mathrm{v})$ ethanol, in water. After washing, the preparation was stained in $0.5 \%(\mathrm{w} / \mathrm{v})$ crystal violet for $c .3$ min., and allowed to dry without heating.

Preparations of these cocci, of one newly isolated strain of Bacillus cereus and one stock culture of a Jensenia sp., were also examined by the technique of Pennington (1950) at ages of culture from $4 \mathrm{hr}$. to 7 days. The method used was exactly as described by Pennington, with the exception that comparisons were made between preparations stained for longer and shorter times, in order to achieve different intensities of coloration. The purpose of this was to differentiate, not only between complete bacilli or cocci in their degree of loss of basophilia, but also between individual cells of a single organism, as illustrated in the figures of Pl. 2.

\section{RESULTS}

The results of the first method are shown in Pl. 1, as applied to a large saprophytic coccus of the Sarcina ureae type. Figures 1-3 are all printed from the same negative. The opacity of the flagella was much less than that of the cells, and Pl. 1, fig. 3, was obtained by screening the latter with a semi-opaque mask. However, the best demonstration of the finer cytological details can only be achieved by the use of separate prints. No difficulty was experienced in observing both the flagella and the cell walls simultaneously in the microscope.

The distribution of the flagella upon the cells of each group is seen to be uneven. Some have several flagella and the majority have none. Plate 1, figs. 4-7, show examples of tetrads with typically uneven distribution of flagella. All these photographs have been printed to demonstrate the flagella in this instance, but their cellular pattern can readily be understood by comparison with Pl. 1, fig. 2. The drawings in Figs. 1-4 were made from similar preparations. Figures 1-3 are different strains of the Sarcina ureae type; Fig. 4 is a small coccus from fish. All show the same characteristic arrangement of flagella upon the cells.

Pennington's method, as applied to cocci in very young cultures, showed groups of cells all of which took the stain well, although usually one pair in each tetrad was more basophilic than the other (Pl. 2, fig. 8). In cultures several days old most of the cells lost their basophilia, although there was again 
a tendency for one pair in each tetrad to stain more deeply than the other (Pl. 2, fig. 9). In actively growing cultures, (12-48 hr. old) the pattern was very strongly marked. Very often one or two cells in each group were strongly basophilic (i.e. 'young') by comparison with the remainder (Pl. 2, fig. 10). This pattern was found also in septate bacilli, where one half of a bicellular rod, or the terminal cell in a filament, was much less darkly stained than the remainder (Pl. 2, figs. 11-13).

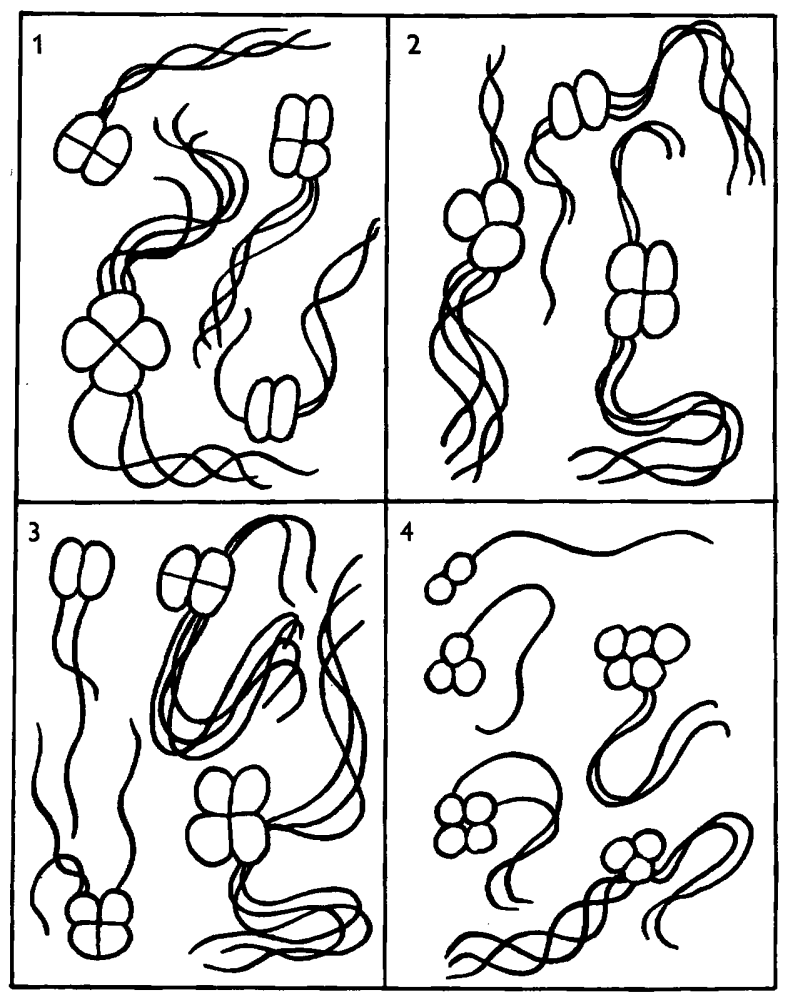

Figs. 1-3. Drawings of three strains of large cocci of the Sarcina ureae type, showing distribution of flagella. Fig. 4. Drawings of a strain of coccus from fish, showing distribution of flagella.

\section{DISCUSSION}

The pattern of flagella upon the cells of motile cocci is in accordance with the theory, previously advanced for rod-shaped bacteria, that cell division is not equational, but is by a process analogous to budding. Thus the mother-cell retains the major part of the original cell wall and flagella (Bisset, 1951). In the case of the cocci examined, the lag between cell division and the development of flagella is so long that the majority of cells in a growing culture have none. Confirmation of this theory is obtainable from the study of groups of dividing cells stained by Pennington's method. Here what appear to be physiologically younger cells are more basophilic after treatment with form- 
Journal of General Microbiology, Vol. 18, No. 3
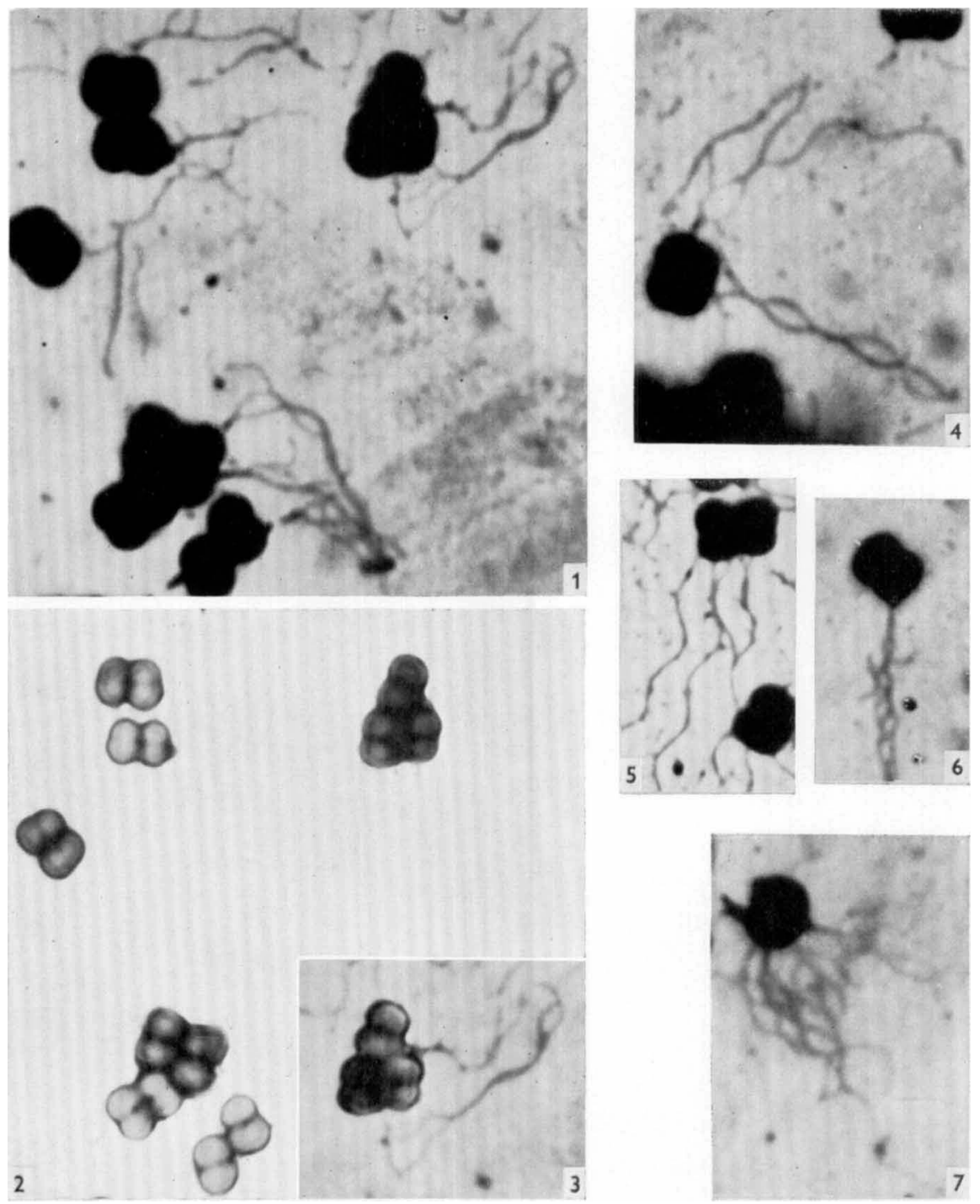

C. M. F. Hale and K. A. Bisset-Figellar development in motile Grampositive cocci. Plate 1

(Facing p. 690) 
Journal of General Microbiology, Vol. 18, No. 3

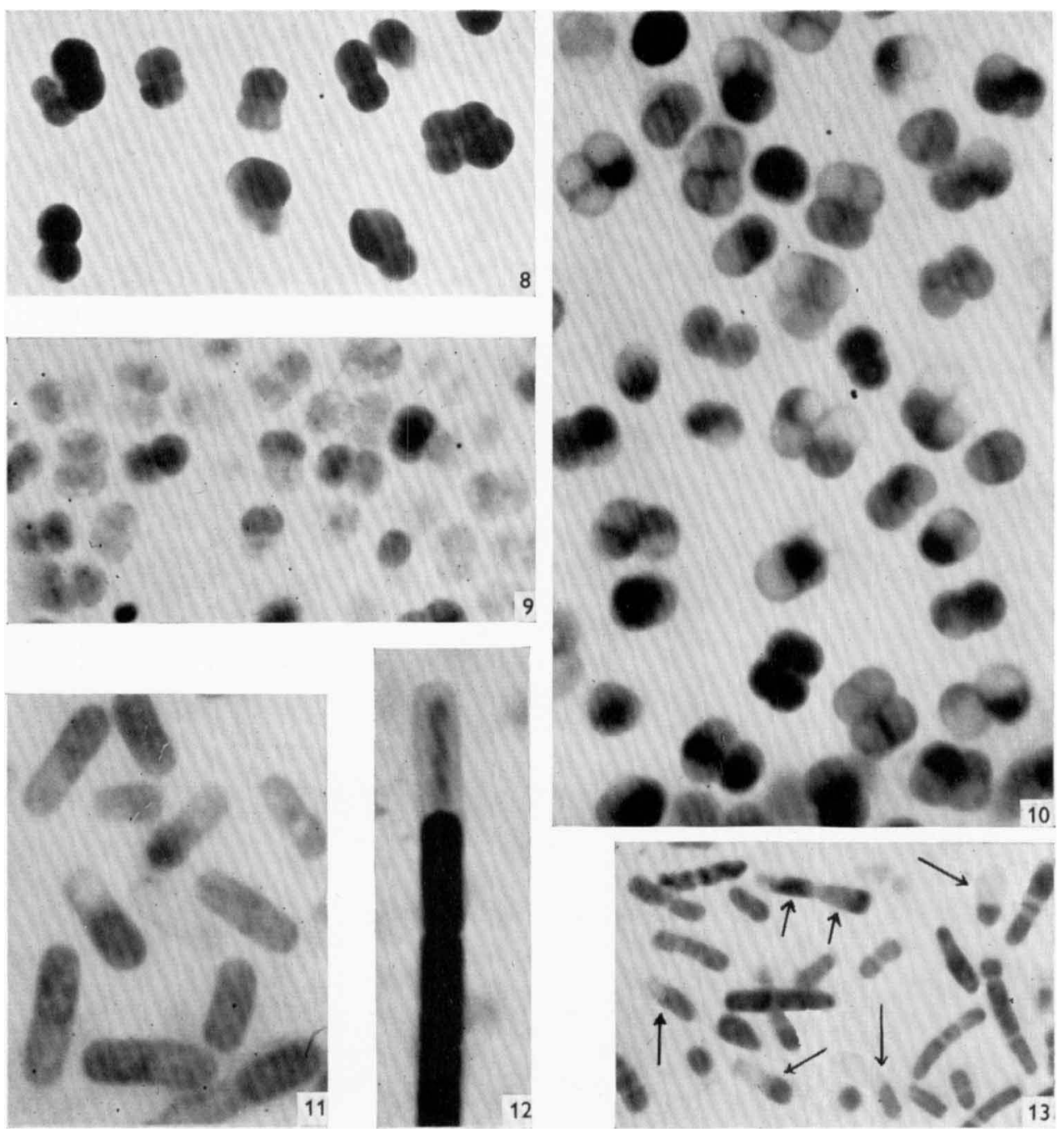

C. M. F. Hale and K. A. Bissei-Flagellar divelopment in motile Grampositive cocci. Plate 2 
aldehyde than are their older neighbours. The arrangement of such groups of cells indicates that not all are of the same physiological age, and that the younger must be regarded as having budded from the older. The pattern in septate bacilli is comparable, and confirms this general theory of bacterial growth.

\section{REFERENCES}

Bisset, K. A. (1951). The development of surface structures on dividing bacteria. J. gen. Microbiol. 5, 156.

Bisset, K. A. \& Pease, P. E. (1957). The distribution of flagella in dividing bacteria. J. gen. Microbiol. 16, 382.

Pennington, D. (1950). A reaction of bacterial cells with formaldehyde. J. Bact. 59, 617.

Shunk, I. V. (1920). A modification of Loeffler's flagella stain. J. Bact. 5, 181.

\section{EXPLANATION OF PLATES}

\section{Plate 1}

All figures are photomicrographs of a large coccus of Sarcina ureaetype, stained todemonstrate flagella and cell walls simultaneously, $\times 2500$.

Figs. 1-3. All these prints are made from the same plate; fig. 1 to show the flagella; fig. 2, less deeply printed, to show the cell walls; fig. 3, printed with an opaque mask over the cells, to demonstrate both flagella and cell walls as well as the method permits.

Figs. 4-7. Tetrads showing typically uneven distribution of the flagella, printed to show the latter only. Cell walls are as in comparable groupings in fig. 2.

\section{Plate 2}

Figs. 8-10. The same coccus as in Pl. 1, stained by Pennington's method, at different ages, $4 \mathrm{hr}$., 7 days and $18 \mathrm{hr}$., respectively, showing loss of basophilia with age, and unequal distribution of 'young' cells in actively growing cultures (fig. 9). $\times 3000$.

Figs. 11, 12. Bacillus cereus, $20 \mathrm{hr}$., showing differential basophilia in bacilli and in a filament. $\times 3000$.

Fig. 13. Jensenia sp., $20 \mathrm{hr}$., showing differential basophilia in septate rods (arrows). $\times 3000$. 